\title{
MODELS TO ESTIMATE CHILLING ACCUMULATION UNDER SUBTROPICAL CLIMATIC CONDITIONS IN BRAZIL
}

\author{
MILECH, Chaiane Goveia - chaiane.gm@hotmail.com \\ Universidade Federal de Pelotas / UFPel
}

SCARIOTTO, Silvia - silviascariotto@yahoo.com.br

Empresa Brasileira de Pesquisa Agropecuária / EMBRAPA - Clima Temperado

\author{
DINI, Maximiliano - maxidini@hotmail.com \\ Universidade Federal de Pelotas / UFPel
}
HERTER, Flavio Gilberto - flavioherter@gmail.com Universidade Federal de Pelotas / UFPel

RASEIRA, Maria do Carmo Bassols - maria.bassols@embrapa.br Empresa Brasileira de Pesquisa Agropecuária / EMBRAPA - Clima Temperado

\begin{abstract}
Chilling requirement is a characteristic that limits temperate fruit crops cultivation under a subtropical climate. Several mathematic models have been developed, differing on the relative value of chilling units, in order to estimate the chilling accumulation on a given site. The present work compared eight of these models using data from hourly temperatures from May to August, from a period of 11 years, collected in Pelotas, RS, Brazil, aiming to characterize the region regarding the chilling accumulation for the cultivation of deciduous fruit trees and to check if a model using average temperatures is suitable enough to be used when hourly temperatures were not available. The eight tested models were: Chilling Hours $\left(\leq 7.2^{\circ} \mathrm{C}\right)$; Chilling Hours $\left(\leq 11^{\circ} \mathrm{C}\right)$; Utah; Low Chill; Dynamic; Mean Temperatures; Positive Utah and Taiwan. The results showed large differences between years, regardless of the model used. However, the Taiwan and Low Chill models seemed more suitable for the estimation of the accumulation of cold in the Pelotas region. The Medium Temperatures model can be used as a valid option since it has a high correlation with the other models and easy data availability.
\end{abstract}

KEYWORDS: chilling accumulation; dormancy; temperate fruits

\section{MODELOS PARA ESTIMAR O ACÚMULO DE FRIO SOB CONDIÇÕES DE CLIMA SUBTROPICAL NO BRASIL}

RESUMO: A necessidade em frio hibernal limita o cultivo de espécies frutíferas de clima temperado, em regiões subtropicais. Para estimar o acúmulo de frio em determinada área, foram desenvolvidos diversos modelos matemáticos, os quais diferem quanto ao valor relativo das unidades de frio em relação a intervalos de temperatura. O presente trabalho comparou oito desses modelos usando dados de temperaturas horárias dos meses de maio a agosto, de um período em 11 anos, coletados em Pelotas, RS, com o objetivo de caracterizar a região, quanto ao acumulo de frio hibernal visando o cultivo de frutíferas de clima temperado e também teve como objetivo verificar se o modelo que usa as temperaturas médias é suficientemente adequado para ser usado quando as temperaturas horárias não estiverem disponíveis. Para isso, foram utilizados oito modelos: Horas de Frio $\left(\leq 7,2^{\circ} \mathrm{C}\right)$; Horas de Frio $\left(\leq 11^{\circ} \mathrm{C}\right)$; Utah; Baixo Frio; Dinâmico; Temperaturas Médias; Utah Positivo e Taiwan. Os resultados mostraram grandes diferenças entre anos, independente do modelo utilizado. Entretanto, dentre os modelos testados, o de Taiwan e o de Baixo Frio mostraram-se mais adequados para a estimativa do acumulo de frio na região de Pelotas. O modelo das Temperaturas Médias pode ser 
utilizado como uma opção válida devido à correlação com os demais modelos e a fácil disponibilidade dos dados.

PALAVRAS-CHAVE: acumulo de frio; dormência; frutíferas de clima temperado.

\section{INTRODUCTION}

Dormancy is the mechanism that deciduous fruit trees use to protect sensitive tissue from unfavorable conditions during the winter. Factors such as unfavorable environmental conditions, chilling temperatures or short photoperiod, generally induce meristem inactivity (CAMPOY et al., 2011). A distinct contrast exists within the Rosaceae regarding environmental control of growth cessation and dormancy. In apple and pear, growth cessation and the onset of dormancy are relatively unresponsive to short day length and instead require low temperature, while in peach and other stone fruits growth cessation and dormancy are induced mainly by short day length and enhanced by low temperature (WISNIEWSKI et al., 2011).

If insufficient chill is accumulated either quantitatively or qualitatively, what is common in subtropical regions, problems such as erratic blooming and leafing delayed leafing, low fruit set and poor fruit quality can occur resulting in a drastic yield reduction (BYRNE and BACON, 1992; CAMPOY et al., 2011).

Temperate species production, in mild winter areas, has been increased rapidly and new industries are being established in regions where none previously existed. Fruit productivity and quality have been gradually improved, in subtropical and tropical highlands through introduction and selection of better adapted varieties based, to a great extent, on their chilling requirements. To supplement the present existing knowledge gap in relation to the cultivarenvironment interactions, the use of chill models to quantify chill accumulation during winter months would help in classifying the environment according to the amount of chill hours (CH) existing in that location (MELKE, 2015).

Up to date, a number of valid models were developed to estimate chilling accumulation under sub-tropical and tropical conditions. However, these models have shown varying results. The limitation in their predictive performance from region to region is probably, at least in part, due to their approaches since they were primarily designed for temperate climate zones (CAMPOY et al., 2011). According to Finetto (2004), another limitation is that the majority of these models only take into account the temperature, in spite of evidences that factors such as light and precipitation are also influential on dormancy suppression. This might be a reason for the divergence of chilling requirement estimation of cultivars of different species. However, it is difficult to work with all of them at once.

The choice of the appropriate model for a certain region requires a comparison between models, to avoid errors in chilling estimation (MELKE, 2015). The Chill Hours model (WEINBERGER, 1950), number of hours below or equal to $45^{\circ} \mathrm{F}\left(7.2^{\circ} \mathrm{C}\right)$ was the first one proposed and up to the present, it is still used by several researchers. Among the proposed chill models, Fishman et al. (1987) considered that the use of the Dynamic model gives good estimation of chilling accumulation in warm winter areas. Also, the model of Positive Utah (LINSLEY-NOAKES et al., 1994) is suggested for warm climate areas, next to the Dynamic Model. The Positive Utah model, a modification of the original Utah (RICHARDSON, 1974), excludes the negation influence of high temperatures. 
Other important alternatives to these classical models include the Mean Temperature Model (BYRNE and BACON, 1992), Taiwan model (OU and CHEN, 2000), Low Chill model (GILREATH and BUCHANAN, 1981) and Hours below $11^{\circ} \mathrm{C}$ model (CHAVARRIA et al., 2000).

In the present work, eight different models were compared to estimate chilling accumulation, using the records of hourly temperatures from May to August, for the years 2004 to 2014, collected in Pelotas, RS. The aim was to characterize the region regarding the chilling accumulation for the cultivation of deciduous fruit trees and test if a model that use average temperature to calculate the chilling accumulation is suitable enough to be used when hourly temperatures were not available

\section{MATERIALS AND METHODS}

This study was carried out in Pelotas, Rio Grande do Sul, Brazil, situated at latitude $31^{\circ} 40^{\prime} \mathrm{S}$ and $52^{\circ} 26^{\prime} \mathrm{W}$ longitude.

The climate in this region is humid subtropical (Cfa - by Köeppen-Geiger Classification), a subtype of subtropical climate, with annual averages of 1,582 $\mathrm{mm}$ rainfall, $18.4^{\circ} \mathrm{C}$ air temperature, $78 \%$ relative humidity, and 342 hours of cold equal to or lower than $7.2^{\circ} \mathrm{C}$ during winter.

For our experiments, hourly temperatures, from May 1 to August 31, collected by the agrometeorology station of Embrapa Clima Temperado, Pelotas, on the years 2004 to 2014, were used.

The data was transferred to an excel file and chill units (CU) were calculated according to each model (Table 1 ). Chilling hours were simply the result of the addition of hours either equal or below $7.2^{\circ} \mathrm{C}$ (RICHARDSON, 1974) or $11^{\circ} \mathrm{C}$ (CHAVARRIA et al., 2000).

Table 1 - Temperature intervals and chill units for four models.

\begin{tabular}{ccccc}
\hline \multirow{2}{*}{ Chill Units } & \multicolumn{4}{c}{${\text { Temperature }\left({ }^{\circ} \mathrm{C}\right)}$} \\
\cline { 2 - 5 } & Utah model $^{1}$ & Low Chill model $^{2}$ & Positive Utah model & \\
\hline 0.0 & $<1.4$ & $<-1.0$ & $<1.4$ & \\
0.5 & $1.5 \sim 2.4$ & $1.8 \sim 7.9$ & $1.5 \sim 2.4$ & \\
1.0 & $2.5 \sim 9.1$ & $8.0 \sim 13.9$ & $2.5 \sim 9.1$ & $<7.2$ \\
0.5 & $9.2 \sim 12.4$ & $\sim 14.0 \sim 16.9$ & $9.2 \sim 12.4$ & $7.3 \sim 15.0$ \\
0.0 & $12.5 \sim 15.9$ & $17.0 \sim 19.4$ & $>12.5$ & $15.1 \sim 26.6$ \\
-0.5 & $16.0 \sim 18.0$ & $\sim 19.5 \sim 20.4$ & & $26.7 \sim 27.8$ \\
-1.0 & $>18.0$ & $>20.5$ & & $>27.8$ \\
\hline${ }^{1}$ Richardson et al. (1974); ${ }^{2}$ Gilreath and Buchanan $(1981) ;{ }^{3}$ Linsley-Noakes et al. $(1994) ;$ \\
${ }^{4}$ Ou and Chen (2000).
\end{tabular}

Chill units are the chilling measure used by the Utah, Low Chill, Positive Utah, Taiwan and Mean Temperature models. These models assign different weights to different ranges of temperatures, with the exception of the Mean Temperature model. This approach reflects research showing that chilling efficiency varied with temperature, including negative chilling accumulation by high temperatures (EREZ and LAVEE, 1971; RICHARDSON et al., 1974). 
For the Mean Temperature model, the two coldest months (June and July) were used in Pelotas, Rio Grande do Sul, Brazil, in degrees Fahrenheit (BYRNE and BACON, 1992), applying the following formula:

Chilling accumulation $=4280-(68.8-$ average of the mean temperature of June and July in ${ }^{\circ} \mathrm{F}$ ).

Chill portions is the unit used by the Dynamic model. This model considers that there is an intermediate product resulting from chilling accumulation and only when enough amount of this product is accumulated it is transformed into a final product. Thus, the first stage is a reversible process consisting of the formation and destruction of an intermediary based on a precursor. The formation of the intermediary depends exclusively on the temperature regime, and the constants of the velocity of formation ( $k 0)$ and destruction ( $k 1$ ) of the intermediary are related to temperature, according to the Arrhenius equation (FRANCE and THORNLEY, 1984). In a second stage the intermediary product is transformed irreversibly into a product or a chill portion. The concentration of the intermediary falls to zero and the dynamic curve exhibits a periodic behavior. The model incorporates a second adjustment to correct the effect of the low temperatures and assumes a critical temperature of $4^{\circ} \mathrm{C}$, below which only a fraction of the intermediary is transformed into a product, thus beginning a new cycle with a concentration of the intermediary that is greater than zero (FISHMAN et al., 1987).

In the present paper, in order to compare the Dynamic model with the others, the chilling portions were multiplied by 28 , considering each portion equivalent to 28 hours of temperature below $6^{\circ} \mathrm{C}$ (PEREZ et al., 2008).

The Pelotas region is the most important peach production area in Brazil. As a result of breeding for low chill cultivars, the majority of them have the flowering period from July (or even earlier) to August. Therefore, in the present work, temperatures from May 1 to August 31 were conventionally used to estimate the chilling accumulation

The total accumulation for each year, the average accumulation for the site, the standard deviation and the coefficient of variation were estimated for each of the eight models. The Spearman correlation coefficient was also calculated among the models.

\section{RESULTS AND DISCUSSION}

The average temperatures of the month of May are relatively higher than the other winter months, being $14.9^{\circ} \mathrm{C}$ the mean temperature and $19.2^{\circ} \mathrm{C}$ the maximum, over an 11-year period (Table 2). Normally the months of June and July are the ones that register lower temperatures, representing greater chilling accumulation. For the years studied, the mean temperatures were $12.8^{\circ} \mathrm{C}$ and $12.0^{\circ} \mathrm{C}$ for June and July respectively whereas $12.6^{\circ} \mathrm{C}$ and $11.8^{\circ} \mathrm{C}$ were the medians. August temperatures are the most variable $\left(S D=2.9^{\circ} \mathrm{C}\right)$, with little influence on overcoming dormancy in most peach cultivars in the region.

Table 2 - Average temperatures from May to August, in the years 2004 to 2014, in Pelotas, Rio Grande do Sul, Brazil. 


\begin{tabular}{|c|c|c|c|c|c|c|c|c|c|c|}
\hline & \multicolumn{4}{|c|}{ Winter months } & \multicolumn{5}{|c|}{ Annual averages } \\
\hline & & May & June & July & August & Mean & SD & Median & Max. & Min. \\
\hline \multicolumn{2}{|c|}{2004} & 14.8 & 14.7 & 11.4 & 13.4 & 13.6 & 2.8 & 13.2 & 18.2 & 10.1 \\
\hline \multicolumn{2}{|c|}{2005} & 15.1 & 15.9 & 13.0 & 14.7 & 14.7 & 2.8 & 14.3 & 19.2 & 11.0 \\
\hline \multicolumn{2}{|c|}{2006} & 14.0 & 13.5 & 15.2 & 12.9 & 13.9 & 3.0 & 13.7 & 18.9 & 9.9 \\
\hline \multicolumn{2}{|c|}{2007} & 12.6 & 9.8 & 9.1 & 11.3 & 10.7 & 2.6 & 10.6 & 14.7 & 6.9 \\
\hline \multicolumn{2}{|c|}{2008} & 15.1 & 12.4 & 15.4 & 13.1 & 14.0 & 2.8 & 13.6 & 19.4 & 10.6 \\
\hline \multicolumn{2}{|c|}{2009} & 15.9 & 11.3 & 9.8 & 14.4 & 12.8 & 3.0 & 12.4 & 17.7 & 9.0 \\
\hline \multicolumn{2}{|c|}{2010} & 15.4 & 12.8 & 11.7 & 11.8 & 12.9 & 2.7 & 12.7 & 17.3 & 9.4 \\
\hline \multicolumn{2}{|c|}{2011} & 14.4 & 11.7 & 10.6 & 11.4 & 12.0 & 2.5 & 11.8 & 16.1 & 8.6 \\
\hline \multicolumn{2}{|c|}{2012} & 16.2 & 12.0 & 9.7 & 15.5 & 13.4 & 3.2 & 13.0 & 18.5 & 9.2 \\
\hline \multicolumn{2}{|c|}{2013} & 14.6 & 12.9 & 11.8 & 11.4 & 12.7 & 3.0 & 12.4 & 17.4 & 8.8 \\
\hline \multicolumn{2}{|c|}{2014} & 15.6 & 14.4 & 14.3 & 14.5 & 14.8 & 2.4 & 14.5 & 18.9 & 11.6 \\
\hline \multirow{5}{*}{$\begin{array}{c}\text { Monthly } \\
\text { averages }\end{array}$} & Mean & 14.9 & 12.8 & 12.0 & 13.0 & & & & & \\
\hline & SD* & 2.8 & 2.6 & 2.8 & 2.9 & & & & & \\
\hline & Median & 14.4 & 12.6 & 11.8 & 12.7 & & & & & \\
\hline & Max. & 19.7 & 17.1 & 16.6 & 17.9 & & & & & \\
\hline & Min. & 11.2 & 9.4 & 8.1 & 9.2 & & & & & \\
\hline
\end{tabular}

*SD=Standard deviation; Max. $=$ Maximum; Min. $=$ Minimum.

Data of yearly chilling units or hours, average and coefficient of variation, considering the years 2004 to 2014, for the eight tested models showed variation among years (Figure 1 ).
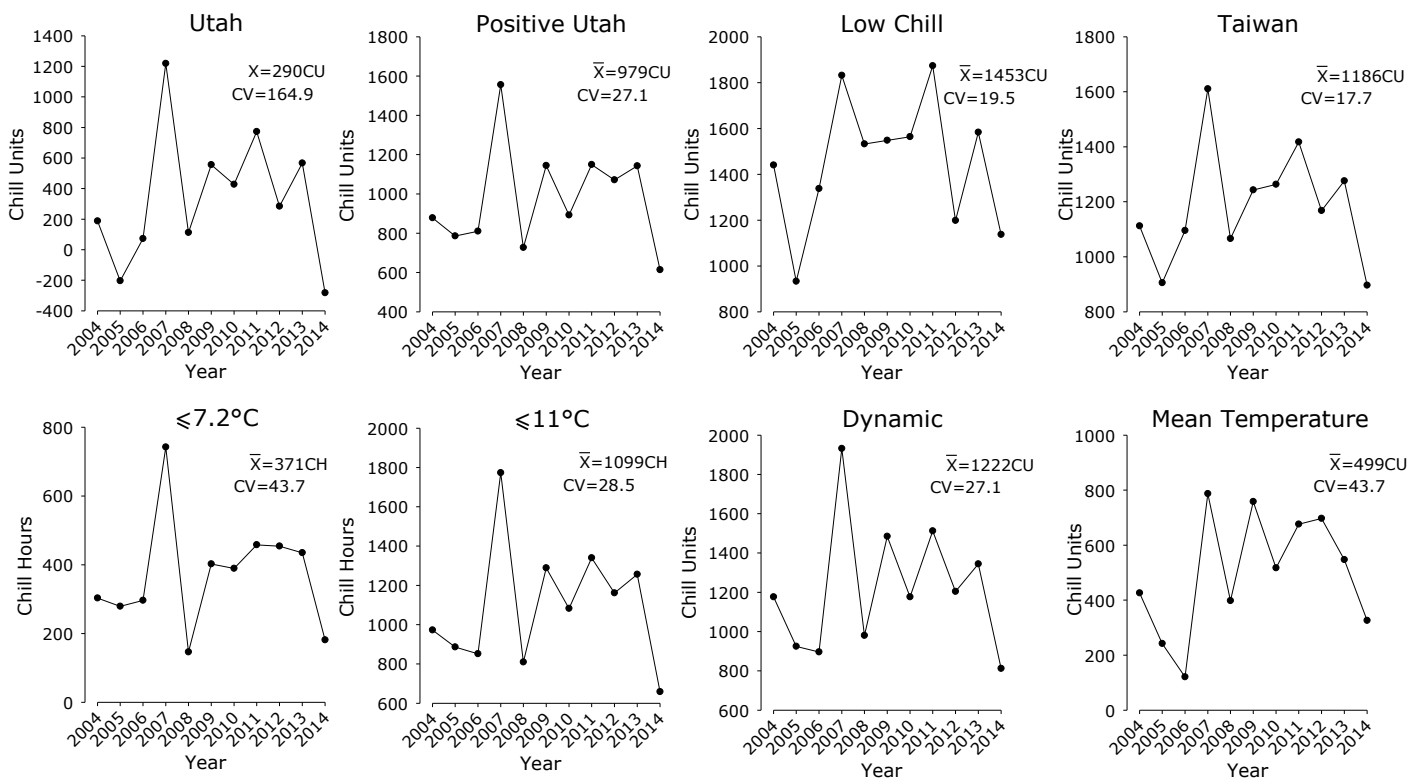

Figure 1 - Chilling accumulation from May to August, in the years 2004 to 2014, in Pelotas, Rio Grande do Sul, Brazil, according to Utah, Positive Utah, Low Chill, Taiwan, Dynamic and Mean Temperature models expressed in Chill Units (CU), and Chill Hours models $\left(\leq 7.2^{\circ} \mathrm{C}\right.$ and $\leq 11^{\circ} \mathrm{C}$ ) expressed in Chill Hours $(\mathrm{CH})$. In Mean Temperature model, portions of chill transformed in $\mathrm{CU}$, considering one portion as being equal to $28 \mathrm{CU}$ of temperature $\leq 6^{\circ} \mathrm{C} ; \overline{\mathrm{X}}=$ Average; $\mathrm{CV}=$ Coefficient of Variation.

The average chilling accumulation in Pelotas for 11 years using the Utah model was calculated as $290 \mathrm{CU}$. Estimations by the Utah model had the largest coefficient of variation (CV) over the years studied $(164.9 \%)$ among all the 
tested models. The range was from 283 negative CU, in 2014, to 1218 positive $\mathrm{CU}$, in 2007. In two out of 11 years evaluated, the chilling accumulation was negative (2005 and 2014). Several studies have reported that the Utah Model does not accurately predict the chilling accumulation in mild climate conditions (EREZ et al., 1990; LINSLEY-NOAKES et al., 1994; CAMPOY et al., 2011). This could explain the high variability of obtained results. This model is not recommended for this area since it was developed in a cooler area, with more uniform winter temperatures.

In Southern Brazil, the occurrence of temperatures above $15^{\circ} \mathrm{C}$ during the winter is frequent, and in the Pelotas area, it is common to have temperatures above $18^{\circ} \mathrm{C}$. This is the reason for the negative values of chilling accumulation, which agrees with Dennis (2003) and (CAMPOY et al., 2011) observations that Utah Model cannot be adopted in warm winter areas.

On the other hand, the positive Utah model (LINSLEY-NOAKES et al., 1994 ) is used in zones with medium chill accumulation and could possibly be used to estimate cold accumulation in Pelotas. The average chilling accumulation in Pelotas for the period studied using this model was calculated to be about 979 CU. The range was from $614 \mathrm{CU}$ (in 2014) to $1555 \mathrm{CU}$ (in 2007). However, it showed more variation (27.1\%) among years than the Taiwan and the Low Chill models (Figure 1). This model is a derivative of the Utah model which does not include the negation aspects of high temperatures. However, it has been found to perform better than the original Utah model in temperate zones (LINSLEYNOAKES et al., 1994; LUEDELING et al., 2009).

The average for the Dynamic model was calculated in $1222 \mathrm{CU}$. In areas with a very mild climate, important differences between the Utah and Dynamic models have been reported (EREZ et al., 1990; EREZ, 2000), which can be observed in this work. The Utah model has been used successfully in cool climates, whereas the Dynamic model seems to better indicate the response of some fruit trees to chilling in warmer and/or subtropical areas (DENNIS, 2003).

The Dynamic model had the same coefficient of variation as the Positive Utah. This model is very interesting by a biological and biochemical point of view, considering what is observed under field conditions. It states that cold is accumulated by a process of two steps. In the first one, an intermediate product is accumulated as a result of cold temperatures. The intermediate product can be reverted by warm temperatures. However, when enough amount of this product is accumulated, it is transformed into another product (the final product) and if a warm temperature occurs, the cold accumulation, (cold portions) does not suffer reversion (FISHMAN et al., 1987).

The Chilling Hours model, total hours of temperatures below or equal to $7.2^{\circ} \mathrm{C}$ (WEINBERGER, 1950), is still used in several regions to calculate chilling hours. The coefficient of variation was $43.7 \%$ and the average accumulation was $371 \mathrm{CH}$. The warmest winter was in the year of 2008, with an accumulation of $146 \mathrm{CH}$ and the coldest in 2007, with $742 \mathrm{CH}$. This model is very simplistic and does not incorporate many of the observed effects of temperature on chill accumulation, such as the negative effect of high temperatures (MELKE, 2015). The $0-7.2^{\circ} \mathrm{C}$ model is dated and many studies have found it to perform poorly in predicting observed changes (ALBURQUERQUE et al., 2008; PEREZ et al., 2008; RUIZ et al., 2007, ZHANG and TAYLOR, 2011). Nonetheless, it has been extensively used in research (BALDOCCHI and WONG, 2008). 
The modified Chilling Hours model considers temperatures less than or equal to $11^{\circ} \mathrm{C}$, and it is used in the Pelotas area (CHAVARRIA et al., 2000), since this is a region of warm winters and temperatures above $7.2^{\circ} \mathrm{C}$ are still efficient in breaking dormancy of the low chill cultivars growing there. For this model, the coefficient of variation was $28.5 \%$ and the average accumulation was $1099 \mathrm{CH}$. Similarly to the previous models, the warmest winter was in 2004, with an accumulation of $658 \mathrm{~h}$ and the coldest in 2007 , with $1173 \mathrm{CH}$.

In the present study, the more homogeneous results were obtained using the Taiwan model (OU and CHEN, 2000) and the Low Chill model (GILREATH and BUCHANAN, 1981). With the Taiwan model, there was an annual average of chill accumulation of 1186.27 chilling units, during the period of 2004 to 2014 and a coefficient of variation of $17.7 \%$. The least cold accumulation was in the year of 2014, corresponding to $896 \mathrm{CU}$ and the largest was in 2007, with 1610 $\mathrm{CU}$, when the Taiwan model was used. According to the Low Chill model the mean was $1453 \mathrm{CU}$ for these 11 years. In a study comparing models of cold accumulation, Maulión et al. (2014) indicated that the coefficient of variation allows a comparison between the models, assuming that the model most appropriate for a given region should reflect the climatic conditions that occur, with less variation between years and an ability to predict more safely the amount of cold accumulated. The authors tested four models (Chilling Hours, Utah, Positive Utah and Dynamic model), concluding that the most suitable ones were the Chilling Hours $\left(\leq 7.2^{\circ} \mathrm{C}\right)$ and positive Utah models. It is possible to emphasize that this work was developed in the province of Buenos Aires, Argentina, which is colder than Pelotas. In this work, the coefficients of variation, of the models selected as the best, were always higher than $20 \%$. In our study, for both the Taiwan model and the Low Chill model, the coefficients of variation were smaller.

Using the Mean Temperature model (BYRNE and BACON, 1992), the results for Pelotas showed an average accumulation of $499 \mathrm{CU}$ with a coefficient of variation of $43.7 \%$ (Figure 2 ). The simplicity of calculating chill accumulation with mean temperatures will aid fruit researchers and growers in several ways. Mean temperature data is routinely kept by cities and state climatologists and is usually easily accessible for tracking chill accumulation for a specific area over long periods of time. Thus, the Mean Temperature model of the coldest months can give a start clue of cultivars which can possibly be adapted to a new area.

The Table 3 shows the Spearman relationship between the different methods of estimating the chilling accumulation. There is a very high correlation between all models. Previous studies (EREZ et al., 1990; EREZ and FISHMAN, 1998 LINSLEY-NOAKES and ALLAN, 1994; MAULIÓN et al., 2015) also have reported this high correlation among models. Therefore, all the tested models could be used in the determination of chilling accumulation in the same way. We recommend the Low Chill and Taiwan models for the Pelotas region, since they were more consistent between the years tested, and the Mean Temperature model as a first approximation for a new area. However, it is interesting to point out that none of these models is perfect but useful to give an estimation making possible to compare different production areas. Adaptations of these models could be made and a next step, to better test the chosen models, could be a test with a standard cultivar, in different areas, comparing the results and/or using controlled temperatures tests. 
Table 3 - Spearman's correlation between for eight models of estimating chilling accumulation

\begin{tabular}{|c|c|c|c|c|c|c|c|c|}
\hline & \multirow[b]{2}{*}{ Utah } & \multirow[b]{2}{*}{$\begin{array}{c}\text { Positive } \\
\text { Utah }\end{array}$} & \multirow[b]{2}{*}{$\begin{array}{l}\text { Low } \\
\text { Chill }\end{array}$} & \multirow[b]{2}{*}{$\begin{array}{c}\text { Taiwa } \\
\text { n }\end{array}$} & \multicolumn{2}{|c|}{ Chilling Hours } & \multirow[b]{2}{*}{ Dynamic } & \multirow[b]{2}{*}{$\begin{array}{l}\text { Mean } \\
\text { Temp. }\end{array}$} \\
\hline & & & & & $\leq 7.2^{\circ} \mathrm{C}$ & $\begin{array}{c}\leq 11^{\circ} \\
\mathrm{C}\end{array}$ & & \\
\hline Utah & - & $* *$ & $* *$ & $* *$ & $* *$ & $* *$ & $* *$ & $*$ \\
\hline $\begin{array}{c}\text { Positive } \\
\text { Utah }\end{array}$ & 0.95 & - & $* *$ & $* *$ & $* *$ & $* *$ & $* *$ & $*$ \\
\hline Low Chill & 0.91 & 0.78 & - & $* *$ & $* *$ & $* *$ & $* *$ & * \\
\hline Taiwan & 0.98 & 0.95 & 0.90 & - & $* *$ & $* *$ & $* *$ & $*$ \\
\hline$\leq 7.2^{\circ} \mathrm{C}$ & 0.89 & 0.95 & 0.67 & 0.91 & - & $* *$ & $* *$ & $*$ \\
\hline$\leq 11^{\circ} \mathrm{C}$ & 0.95 & 0.99 & 0.75 & 0.93 & 0.95 & - & $* *$ & $*$ \\
\hline Dynamic & 0.97 & 0.96 & 0.81 & 0.92 & 0.90 & 0.97 & - & $*$ \\
\hline $\begin{array}{l}\text { Mean } \\
\text { Temp. }\end{array}$ & 0.86 & 0.87 & 0.65 & 0.80 & 0.85 & 0.88 & 0.92 & - \\
\hline
\end{tabular}

In the lower diagonal the Spearman's correlation value. In the upper diagonal: *, **; significant at $\mathrm{P}<0.05$ or $\mathrm{P}<0.01$, respectively.

\section{CONCLUSION}

All tested models showed great differences among years for chilling accumulation in the Pelotas-RS area.

The Low Chill and Taiwan models can be used for the Pelotas region, since they are more consistent and were developed in mild winter regions.

The Mean Temperature model can be used for a rough estimation, if hourly temperature data is unavailable.

\section{ACKNOWLEDGMENTS}

The CAPES (Coordenação de Aperfeiçoamento de Pessoal de Nível Superior) and Embrapa Clima Temperado.

\section{REFERENCES}

ALBURQUERQUE, N.; GARCÍA-MONTIEL, F.; CARRILLO, A.; BURGOS, L. Chilling and heat requirements of sweet cherry cultivars and the relationship between altitude and the probability of satisfying the chill requirements. Environmental and Experimental Botany, v. 64, p. 162-170, 2008.

BALDOCCHI, D.; WONG, S. Accumulated winter chill is decreasing in the fruit growing regions of California. Climatic Change, v. 87, p. 153-166, 2008.

BYRNE, D.H.; BACON, T.A. Chilling estimation: its importance and estimation. The Texas Horticulturist, v. 5, p. 8-9, 1992.

CAMPOY, J.A.; RUIZ, D.; EGEA, J. Dormancy in temperate fruit trees in a global warming context: A review. Scientia Horticulturae, v. 130, p. 357-372, 2011. 
CHAVARRIA, G.; RASEIRA, M.C.B.; Zanandrea, A. Chilling requirement in peach. In: Prunus Breeders Meeting. Summaries... Pelotas: Embrapa CPACT, 2000, v. 1, p. 78-80.

DENNIS, F.G. Problems in standardizing methods for evaluating the chilling requirement for the breaking of dormancy in buds of woody plants. HortScience, v. 38, p. 347-350, 2003.

EREZ, A.; FISHMAN, S. The dynamic model for chilling evaluation in peach buds. Acta Horticulturae, v. 465, p. 507-510, 1998.

EREZ, A.; FISHMAN, S.; LINSLEY-NOAKES, G.C.; ALLAN, P. The dynamic model for rest completion in peach buds. Acta Horticulturae, v. 276, p. 165-174, 1990.

EREZ, A., LAVEE, S., Effect of climatic conditions on dormancy development of peach buds. 1. Temperature. Journal of the American Society for Horticultural Science, v. 96, p. 711-714, 1971.

EREZ, A. Bud dormancy: phenomenon, problems and solutions in the tropics and subtropics. In: Erez, A. (Ed.), Temperate Fruit Crops in Warm Climates. Kluwer Academic Publishers. The Netherlands, 2000, p. 17-48.

FINETTO, G. A. Investigation of the effects of light and rain on overcoming of dormancy in some apple cultivars. Acta Horticulturae, v. 662, p. 93-100, 2004.

FISHMAN, S.; EREZ, A.; COUVILLON, G. A. The temperature dependence of dormancy breaking in plants-mathematical analysis of a two-step model involving a cooperative transition. Journal of Theoretical Biology, v. 124, p. 473483, 1987.

FRANCE, J.; THORNLEY, J.H.M. Mathematical models in agriculture. Butterworths, London, UK, 1984. 335 p.

GILREATH, P.R.; BUCHANAN, D.W. Rest prediction model for low-chilling 'Sungold' nectarine. Horticultural Science, v. 106, n. 4, p.426-429, 1981.

LINSLEY-NOAKES, G.C.; ALLAN, P. Comparison of two models for the prediction of rest completion in peaches. Scientia Horticulturae, v. 59, n. 2, p. 107-113, 1994.

LINSLEY-NOAKES, G.C.; ALLAN, P.; MATTHEE, G. Modification of rest completion prediction models for improved accuracy in South African stone fruit orchards. Journal of the Southern African Society for Horticultural Sciences, v. 4, n. 1, p. 13-15, 1994.

LUEDELING, E.; ZHANG, M.; MCGRANAHAN, G.; LESLIE, C. Validation of winter chill models using historic records of walnut phenology. Agricultural and Forest Meteorology, v. 149, p. 1854-1864, 2009.

MAULIÓN, E.; VALENTINI, G.H.; KOVALEVSKI, L.; PRUNELLO, M.; MONTI, L.L.; DAORDEN, M.E.; QUAGLINO, M.; CERVIGNI, G.D.L. Comparison of methods for estimation of chilling and heat requirements of nectarine and peach genotypes for flowering. Scientia Horticulturae, v. 177, p. 112-117, 2014.

MELKE, A. The physiology of chilling temperature requirements for dormancy release and bud-break in temperate fruit trees grown at mild winter tropical climate. Journal of Plant Studies, v. 4, n. 2, 2015. 
OU, S.K.; CHEN, C.L. Estimation of the chilling requirement and development of a low-chill model for local peach trees in Taiwan. Chilean Journal of Agricultural Research, v.46, n. 4, p. 337-350, 2000.

PEREZ, F. J.; ORMENO, J. N.; REYNAERT, B.; RUBIO, S. Use of the dynamic model for the assessment of winter chilling in a temperature and a subtropical climatic zone of Chile. Chilean Journal of Agricultural Research, v. 68, p. 198206, 2008.

RICHARDSON, E.A.; SEELEY, S.D.; WALKER, D.R. A model for estimating the completion of rest for 'Redhaven' and 'Elberta' peach trees. HortScience, v.1, p. 331-332, 1974.

RUIZ, D.; CAMPOY, J.; EGEA, J. Chilling and heat requirements of apricot cultivars for flowering. Environmental and Experimental Botany, v. 61, p. 254263, 2007.

WEINBERGER, J.H. Chilling requirement of peach varieties. Proceedings of American Society of Horticultural Science, v. 56, p. 122-128, 1950.

WISNIEWSKI, M.; NORELLI, J.; BASSETT, C.; ARTLIP, T.; MACARISIN, D. Ectopic expression of a novel peach (Prunus persica) CBF transcription factor in apple (Malus $X$ domestica) results in short-day induced dormancy and increased cold hardiness. Planta, v. 233, p. 971-983, 2011.

ZHANG, J.; TAYLOR, C. The Dynamic model provides the best description of the chill process on 'Sirora' pistachio trees in Australia. Horticultural Science, v. 46, n. 3, p.420-425, 2011 